\title{
PERSATUAN PEMUDA MUSLIM SE-EROPA: Its Qualified Founders, Progression and Nature
}

\section{Sujadi}

Faculty of Adab, Sunan Kalijaga State Islamic University Yogyakarta, Indonesia

\section{Abstract}

This article concentrates on the history of Persatuan Pemuda Muslim seEropa (PPME, Young Muslims Association in Europe), depicting its founders'qualifications, historical founding, and nature, which has been against practical politics, and restructure and expansion. This association remains the largest Indonesian Islam-oriented Muslim association in Europe. However, there has been little research done on this association, despite its significant contributions to the socio-cultural and religous activities of Indonesian Muslims in Europe, particularly in the Netherlands and Germany. Therefore, this article aims to fill the gap in academic research, dealing with its creation and development up till the present. To deal with this subject, a historical method emphasizing a chronological approach is applied. In addition to historical evidence, oral sources were primarily used due to the scarcity of written documents.

Keywords: Indonesian nationalism, traditionalists, modernists, progressive muslims

\section{A. Introduction}

This article is concerned with the process of the foundation of Persatuan Pemuda Muslim se-Eropa (PPME-Young Muslim Association in Europe) and its development over time. To gain an understanding of this subject, it is important to start with a discussion of the ideals and actions of its founders. Additionally, its nature and objectives, structure 
and expansion, status and activities will be other concerns.

To begin with, it is necessary to be acquainted with the reasons for taking a trip to the Netherlands or Germany and the socio-educational backgrounds of some of the founders. Familiarity with these figures will assist in gaining the proper understanding of the above mentioned topics. The founders of the association were mostly Indonesian. Two were non-Indonesians, with one being Dutch and the other Yamani. Nevertheless, they, at least, still had a historical relationship to Indonesia. The Dutch founder was of Indonesian descent, and the Yamani's father had participated in the struggle for Indonesian independence.

The founders were youths, ${ }^{1}$ not all had graduated from university but they had similar ideals. They craved for the preservation and strengthening of Islamic brotherhood among Indonesian Muslims residing in the Netherlands, through da'wa activity, unconditioned networking and joint activities, and the creation of social endeavors. The following were prominent figures.

The first figure was H. Abdul Wahid Kadungga, a founder who was later elected the first leader of the new organization. His travel to Germany aimed at furthering his higher education. He left Indonesia around the end of the 1960s and studied at Cologne University, Germany. ${ }^{2}$ He did not graduate from university but the Sekolah Menengah Ekonomi Atas (SMEA, Senior High School for Economics) in Makassar, South Celebes. ${ }^{3} \mathrm{He}$ was a former activist of Pelajar Islam Indonesia (PII). ${ }^{4} \mathrm{He}$ was very concerned with da'wa activities and Islamic politics. This cannot

1 The definition of youth varies. The United Nations defines a person who is 15 to 25 as a youth. However, in some countries the definition of youth is extended, according to William D. Angel, downward to include young people who are 11 or 12, and upwards to the 30-35 age group. William D. Angel, Youth Movement of the World (UK: Longman, 1990), p. xii. The last classification was chosen to label the founders of PPME as youths because they, especially those who graduated from university, were more than 25 years old.

2 http:// counterterrorisminfo.wordpress.com/2002/12/24/abdul-wabid-kadungga, quoted on 23 July 2008 at 1:27 a.m., Leiden.

3 Herry Nuhdi, "Berdiri Melawan Amerika", in Sabili, No. 16, Year XII, 27 February 2004, p. 62.

4 Interview with A. Hambali Maksum, the Secretary of the First Period of PPME's Board, 17 May 2008 at His Apartment, The Hague. 
be disassociated from his involvement in the PII, given his studies at the Sekolah Menengah Islam (Islamic Junior High School) and SMEA in the aforesaid city, and his participation, as the leader of PII on behalf of the Makassar branch, in its national congress held in Medan, 1962. This student association had led him to meet Adam Malik, the former vice president of the Republic of Indonesia. ${ }^{5}$ It is worth mentioning that the PII was one of the Muslim organizations involved in the solidarity demonstrations held on 13 September, 1965, for Himpunan Mahasiswa Islam (HMI), which was discredited by Partai Komunis Indonesia (PKI) as anti-Soekarno. ${ }^{6}$ After a few years in Europe, in Germany and the Netherlands, he returned to Indonesia and worked for Dewan Dakwah Islam Indonesia (DDII). He became the private secretary of M. Natsir. In 1974, he was arrested and put in prison, together with other Islamic activists, on the instruction of the New Order government. Having been released, despite his being ordered to stay in the city, he traveled to the Netherlands as an asylum seeker, due to the treatment of the ruling Indonesian government. From then on, the regime no longer recognized him as Indonesian. In response, he said, "actually I do not wish to be a black Dutch [possessing coloured skin and black hair]. I am not the rebellious of the state and the enemy of the nation". ${ }^{7}$ It is also worth noting that he was a son-in-law of Kahar Muzakkar, a leader of the Darul Islam, ${ }^{8}$ for the region of Celebes.

The second figure was $\mathrm{H}$. Ahmad Hambali Maksum, the first secretary of the board of PPME. After completing his primary school,

\footnotetext{
5 Herry Nuhdi, "Berdiri", Sabili, p. 61-62.

6 Dwi Purwoko, Pemuda Islam di Pentas Nasional (Jakarta: Bonafida Cipta Pratma, 1993, p. 122-124.

7 Herry Nuhdi, "Berdiri", in Sabili, p. 61-63

8 http:/ / wnw.munindo.brd.de/artikel/ artikel_04/000129_3.htm, quoted on 23 July 2008 at 1:11 a.m., Leiden. It is also important to mention here that during the 1940s, Kahar Muzakkar was "one of the local [South Celebes] leaders of the Pemuda Muhammadiyah,... the Hizbul Wathon, the Muhammadiyah Boy scout movement". C. van Dijk, Rebellion under the Banner of Islam: the Darul Islam in Indonesia, The Hague: Martinus Nijhoff, 1981, p. 155. In 1954, he founded Pemuda Islam Jihad, shortly after he had proclaimed Celebes part of Negara Republik Islam Indonesia (in 1953); Ibid., p. 189. Therefore, the founding of this association cannot be divorced from his struggle for Islamic revolution through the new Islamic state.
} 
he learned Islam in various pesantrens such as pesantren Tebuireng and the modern pesantren Gontor, Ponorogo. ${ }^{9}$ Then, in 1957, he furthered his learning in the pesantren Jamsaren. ${ }^{10}$ Afterwards, he traveled to Mecca, Saudi Arabia to continue his studies in a senior high school called Däru'lUlum, at which madhhabs in Islamic jurisprudence were still taught. His interest in organizational activities can be seen in his active involvement in the PPI of the country. Furthermore, he enrolled himself in al-Jami' ${ }^{\prime} a h$ (university) of Bagdad for his undergraduate program. During his time in this city, his interest in joining organizational activities continued. He joined an organization of Muslims called Keluarga Pemuda Nahdlatul Ulama (KPNU). ${ }^{11}$ Finally, he graduated from the university in 1969. Having completed his studies, he chose to live in the Netherlands, where he had resided for one year. In this country, he finally got a job as a teacher in the Sekolah Indonesia Nederland (SIN, The Netherlands Indonesian School). ${ }^{12}$ Starting in 1971, he was a part time teacher in the school. In addition, he was also a part time official for a Dutch insurance company. Then, in 1974, he moved to Germany, where he lived for a year and

9 Interview with A. Hambali M, 17 May 2008, The Hague.

10 See: Mufti Ali, "The Contextualization of Fiqh al-Ibādah among Indonesian Religious Teachers and Their Communities in the Circle of PPME in Amsterdam and The Hague", in Sadia Rashid (Ed.), Hamdrad Islamicus, April-June, Vol. XXX, No. 2, Pakistan: Hamdrad Foundation, 2007, p. 68.

11 Interview with A. Hambali M, 17 May 2008, The Hague.

12 This school was founded on 15 June 1965, and was inaugurated by His Excellency Indonesian Ambassador, Mr. Soedjarwo Tjondronegoro on 17 August 1965. The name 'SIN' was officially based upon the Decision of Minister of Education and Culture dated on 15 August 1995. This school aimed to provide official education to Indonesian children and youths in the Netherlands. It consisted of primary, junior high and senior high schools following the curriculum of Indonesia's national education system. It used Indonesian as the introductory language. It was managed by the Ministry of Foreign Affairs through the Indonesian Embassy, and was technically supervised by the Attaché of the Department of Education and Culture. In 2003, the number of registered students was 36, with 15 teachers. Read: Abdul Manan Zaibar, The Indonesian Program for the Islamic Religious Education of the Indonesian Children in the Netherlands (Thesis), INIS: Leiden, 2003, p. 151-153. Now, its level of primary school no longer exists. Interview with Sitti Atikah Zofwaan, a Recently Retired Teacher of this SIN, Sunday 11 August 2008 at 20.30, at Her House, The Hague. 
half ${ }^{13}$ studying philosophy and German language at Cologne University. Then, because of a company regulation obliging its officials to work full time, he made the decision to leave his job as a teacher at the school in 1975. As an Islamic activist and one of the founders of PPME, in the mid-1990s, he joined the branch of ICMI in the Netherlands. From the outset of his stay in the Netherlands, he had no intention, however, to reside permanently in the country. This was in opposition to the fact that he had been living in the Netherlands since the early 1970s, up to the present while enjoying his life as a pensioner of the insurance company, and as an Islamic preacher and imam for the Indonesian community in the Netherlands. ${ }^{14}$

The third was H. Mochammad Chaeron. He traveled to the Netherlands in the early 1970s, through Saudi Arabia, in order to be able to further his tertiary education in Germany, in addition to his craving to have a proper job. During his studies at Gadjah Mada University, he was an activist of Ikatan Mahasiswa Muhammadiyah (IMM). Additionally, he was a journalist for Abadi, the Masyumi's newspaper. He graduated from Gajah Mada University, specializing in publicity, in August 1967. Because of his involvement with Abadi, he traveled, together his colleagues, to Saudi Arabia and other Middle Eastern countries, before finally residing in the Netherlands. His goal of further studies was not achieved due to financial problems and his involvement in the SIN, as a teacher, which took a lot of his time and occupied his attention. He became the headmaster of the school in 1972, after his involvement in the preparation process of founding PPME. This figure was also a member of ICMI in the Netherlands, founded in the early 1990s. As the Indonesian embassy limited the profession as a teacher at the age of 60 , Chaeron retired from his position as a teacher in 2003 and never took another job afterwards, although he was willing to teach. Two years after his resignation, Chaeron passed away due to sickness in $2005 .^{15}$

The last was Abdurrahman Wahid (Gus Dur), who was later elected as a formateur of the new organization, given the right, together with other two formateurs, to design and compose the board of the new

\footnotetext{
13 See: Mufti Ali, “The Contextualization of Fiqh al-Ibādah,” p. 68-69.

14 Interview with A. Hambali M, 17 May 2008, The Hague.

15 Interview with S. Atikah Z., 11 August 2008, The Hague.
} 
organization. To begin with, in the mid-1960s, soon after arriving in Cairo for studies at Al-Azhar, he was elected as the chairperson of PPI (the Association of Indonesian Students) in Egypt. This led him to develop social networks of Indonesian students across the Middle East. Another important experience was his regular work at the Indonesian Embassy in Cairo, mainly as a translator from Indonesian to Arabic or English. Through this employment, he had inside access to important and actual issues such as the tension between Islam and communism and the allegedly 1965 communist revolt in Indonesia. He was also ordered by the embassy to investigate and to deliver a report on the political leanings of Indonesian students in the Middle East. Having completed his studies for an undergraduate program at al-Jami'ah (university) in Bagdad, he traveled, from Iraq, to the Netherlands in the early 1970s to further his studies. He was extremely eager to enroll in Leiden University, yet, despite spending six months in the country, the university would admit him only for the undergraduate, not graduate, program. This fact bothered him because he could not further his tertiary education in Europe. He finally returned to Indonesia in May 1971, after the establishment of the PPME. ${ }^{16}$

Based upon these facts, the founders of PPME cannot be precisely grouped into one of Twanna A. Hines' classifications of immigrant populations in the Netherlands, namely, "guest workers recruited to fill low to unskilled occupations starting after World War II, migrants from former colonies, and post-Cold war refugees from newly independent Eastern European". ${ }^{17}$ To categorize them into this group required bilateral agreements ${ }^{18}$ despite some of the founders' intention to find a job. They were, however, not under such an agreement. They, also, could not be grouped into another group defined by Hines, namely the group that had "historical, social, cultural, and political relationship with

16 Greg Barton, Gus Dur: the Authorized Biography of Abdurrabman Wabid (JakartaSingapore: Equinox, 2002), p. 83-101. Read also: DPP PPME, Laporan DPP Musyawarah I (The Hague: PPME, 1973).

17 Twanna A. Hines, "The Myth of Ethnic Equality", in Maura I. Toro and Marixsa Alice, Migration and Immigration: a Global View (USA: Greenwood Press, 2004), p. $149-150$.

18 Ibid. 
the Netherlands due to its colonial past". ${ }^{19}$ They were merely migrants, some of whom craved a proper job, while others aimed to further their studies, without the aforesaid connections, with the exception of the political relationship between the colonial power, the Netherlands, and the colonized, Indonesia prior to the Indonesian independence. The depiction provided by Dassetto and Nonneman of Muslim immigrants who were 'mostly men and usually without families in between the early 1960s and the mid-1970s, particularly, for those in the Netherlands ${ }^{20}$ could describe the founders of PPME, who were mostly unmarried despite some of them being more than 30 years old. ${ }^{21}$

\section{B. Worthy Characteristics of PPME's Founders}

Prior to the establishment of PPME, its founders lacked of legal and political knowledge of the Netherlands and the prevailing Muslim and student organizations in the country.2 They had, also, no permanent residence permit. ${ }^{23}$ Accordingly, these conditions hardly afforded them the opportunity to become the forerunner youths i.e. those "who challenge the existing civilization by injecting ideas, values, actions to promote a new and more equitable order and to promote unity, integration and understanding between ethnics and civilizations of different socio-economic, cultural and/or religious background". ${ }^{24}$ As a matter of fact, they did not struggle for the aforementioned subjects but their own concerns.

19 Ibid.

20 Felice Dassetto and Gerd Nonneman, in "Islam in Belgium and the Netherland: towards a Typology or 'Transplanted' Islam”, in Gerd Nonneman et. al., Muslim Communities in the New Europe (UK: Garnet Publishing, 1996), p. 191.

21 Interview with A. Hambali Maksum, 12 August 2008, The Hague and Interview with Saleh al-Nahdi, the nephew of Amir al-Hajri who was one of the PPME's founders, stated that his nephew was already married before its establishment. 12 August 2008, at 22.30 at His House, Leiden,

22 Read: DPP PPME, Kronologis Sekitar Berdirinya “PPME”, in DPP PPME, Laporan, 1973.

23 Interview with A Hambali M, 17 May 2008, The Hague.

${ }^{24}$ William D. Angel, Youth, p. 8. 
In the first place, they had realized and were committed to Islamic teaching, conducting da'wa and upgrading umma. These characteristics and the success of some of the founders in their studies ${ }^{25}$ could have undermined their aforesaid handicaps. Their fellow Indonesian Muslims, who had been residing in the Netherlands and performing their religious teaching under difficult conditions in a non-Muslim society with a lack of Indonesian experts on Islam, drew their attention. ${ }^{26}$ Their fellow Indonesian Muslims were mostly not students. This was based upon the clarification that one of the primary concerns of their Muslim friends was their marital status. They strongly desired to renew their wedding ceremony on an Islamic basis. In addition, they wished to be buried with an Islamic funeral. ${ }^{27}$

Such socio-religious conditions differed from those of the Muslim soldiers of KNIL (Koninklijke Nederlandse Indische Leger) of Ambon, part of Moluccas, Indonesia. Initially, they resided in Friesland and subsequently in Walwijk and Ridderkerk. These Muslims were socioreligiously well organized in their new country. Their problems were being addressed by a Muslim leader, Akhmad Tan and they had had their own mosque. Lastly, their funerals were being performed according to Islamic teaching. ${ }^{28}$

The problems of these, mostly non-Moluccan, Indonesian Muslims appeared to fall outside the concerns of many Indonesian students, who had resided since1950s in Europe. In addition to being away from their family and the opportunities of their homeland, Indonesia, they were of the opinion that the cultural, political and social structures differences, found in their host countries, had prevented them from fully adapting to their new social and intellectual environment. ${ }^{29}$ This fact suggested

25 Interview with A. Hambali M, 17 May 2008, The Hague.

26 Interview with A. Hambali M, 17 May 2008, The Hague. Also read: Muhamad Hisyam, Persatuan Pemuda Muslim Se Eropa (The Hague: YMAE, 1996), p. 21.

27 Interview with A. Hambali M, 17 May 2008.

28 See: N.J.G. Kaptein, "Islam in Present-Day Dutch Society", in W.A.L. Stokhof and N.J.G. Kaptein (Eds.), Beberapa Kajian Indonesia dan Islam (Jakarta: INIS, 1990), p. 201-202.

29 Panitia, Konperensi Pelajar Indonesia se-Eropa (Hennef: Panitia Konperensi, 1955), p. 62-64. 
that they had not prioritized religious affairs. They preferred to concern themselves with social and political matters, not religious consciousness. ${ }^{30}$

Secondly, the goal of creating a vehicle aimed at Islamic da'wa activities $^{31}$ in the Netherlands was in the founders' minds. ${ }^{32}$ To achieve this goal they only had the spirit and belief that God would bestow assistance on them for such a good objective. ${ }^{33}$ It seemed that the conducive political situation in Indonesia after the Communist revolt had encouraged them to embody this dream. In Indonesia, during the early years of New Order regime, da'wa activities were under strict control of the regime, and required official permission. The best example of this was the establishment of Dewan Dakwah Islamiyah Indonesia (DDII) in 1967, which chose the name Yayasan Dakwah (Da'wa Foundation) instead of being a political party or mass organization. One reason for this was that its founders' activities were censored by the government. In addition, the founding of a new organization had to obtain permission while a foundation required no membership but only founders, supporters and sympathizers, all of whom were so-called Keluarga Dewan Dakwah. No official permission was required, only a notary's decision. ${ }^{34}$

These conditions created an uncomfortable atmosphere for some Islamic preachers in Indonesia. On the contrary, in the Netherlands, there were no significant external barriers from the government for the realization of their goals. ${ }^{35}$ The existence of other Muslim organizations

30 Basuki Gunawan, Indonesische Studenten in Nederland (The Hague: N.V. Uitgeverij W. van Hoeve, 1966), p. 169.

31 When describing about youth movement William D. Angel defined the term 'movement' as "a large number of people banding together in order to alter, supplement, or preserve some portion of the existing order". William D. Angel, Youth, p. xii. Therefore, this term was not apt for their goal, namely performing Islamic propagation and upgrading umma, due to their small number i.e. twenty two youths. However, this number has recently continued to increase, and their goals have changed. They were concerned not only with the abovementioned subjects but also with social, cultural, and academic affairs. Thus, the term of movement applies to PPME.

32 Interview with A Hambali M., 17 May 2008, The Hague.

33 Muhamad Hisyam, Persatuan, p. ii.

34 Read: Asna Husin, Philosophical and Sociological Aspects of Da'wah: a Study of Dewan Dakwah Islamiyah Indonesia (USA: UMI, 1998), p. 31.

35 Interview with A. Hambali M., 17 May 2008, The Hague. 
encouraged the goals of the founders. ${ }^{36}$ As a matter of fact, in the $1960 \mathrm{~s}$ and early 1970s, Muslim organizations of nationals from Morocco and Turkey, living in the Netherlands, had been created. ${ }^{37}$

It is worth noting that, between the 1960s and 1983, societies in the Netherlands faced an ambiguous policy from the government. The Dutch 'Pillarization' ${ }^{38}$ system of the late nineteenth century had eroded by the 1960s. After this period, 'de-pillarization' was taking over it. Nonetheless, the system remained powerful. Political parties, trade unions, schools, hospitals, media, and universities remained under the organizational lines of the traditional pillars. ${ }^{39}$ This situation encouraged Muslims in the country to create their own organizations. Seemingly, the goals of the founders of PPME were in line with the 'Pacification' process to which the government had, at the time, been attempting through social participation and integration within society. This process enabled leaders, including imams or Muslim leaders, to "develop an extensive network with elites of other pillars, deal effectively with them, and contain conflicts between pillars". ${ }^{40}$ The founders' goal clearly showed their rational calculation of the prevailing political situation both in the host country and in their home country. Therefore, their goals were not utopian.

Lastly, their volunteerism should not be ignored. Their willingness to attend a series of gatherings for the founding of the new organization

36 Ibid.

37 M. Ali Kettani, Muslim Minority in the World Today (London and New York: Manshell Publishing Limited, 1986), p. 44.

38 This system was based on different life styles. People from different backgrounds-Catholics, Protestants, Liberal and Socialist-were regionally concentrated and lived in different social compartement. It emerged in the period between 1870-1920. It functioned as the vehicle for democratization and emancipation in various fields. Pacification, through the development of extensive networks in such a way that conflicts among the pillars could be reduced was, then, the logical result. Despite its erosion since the 1960s, through depillarization, it remained functional. This system was called a pillarized society. The presence of Muslims in the Netherlands triggered the emergence of a re-pillarization process, in which 'migrat-pillar' was created, and included by the government. Read: Ruben Gowrichan and Bim Mungra, "The Politics of Integration in the Netherlands", in W.A.R. Shadid and P.S. van Koningsveld, Muslims in the Margin (Kampen: Kok Pharos, 1996), p. 114-120, and 123-129.

39 Ibid., p. 116-117.

40 Ibid. 
and their desire to share ideas serves as evidence. ${ }^{41}$ Their volunteerism is even more evident in their willingness to travel from city to city, and country to country, Germany to the Netherlands, in order to attend meetings for the establishment of PPME. ${ }^{42}$ They did not even object to giving their belongings for the sake of Islamic propagation. The demand for their socialization as a migrant group should not be, in this case, put aside. $^{43}$

The aforesaid concerns hint at their consciousness of how their beliefs differed from that of the majority in their host country, and their great solidarity, despite their various citizenships, in responding to the socio-religious needs of Indonesian Muslims in the country. This consciousness and solidarity was useful as social capital for their existence as "a religious minority group". ${ }^{44}$ These were extremely important for coping with the barriers in their new environment even though they remained politically inferior. ${ }^{45}$

\section{PPME: the Result of Progressive and Democratic Actions}

The establishment of a new Muslim organization called 'Persatuan Pemuda Muslim Se-Eropa' (PPME) was the result of the progressiveness of its founders. The many meetings which would eventually lead to its founding took place from early January to the middle of April 1971. In each gathering their ideas always moved ahead. Their idealism and fighting spirit of founding a Muslim organization strengthened their progressiveness. Then, it was intensively discussed in a series of meetings, with participants coming from the Netherlands ${ }^{46}$ and Germany. ${ }^{47}$

In early January 1971, the first meeting was held in the house of a Dutch man, Rahmat Zitter, in Barenstraat 4, The Hague. In this house,

41 See: Muhamad Hisyam, Persatuan Pemuda Muslim se-Eropa (The Hague: DPP PPME, 1996), p. 23-25.

42 DPP PPME, Laporan, 1973.

43 Interview with A. Hambali M., 17 May 2008, The Hague.

44 M. Ali Kettani, Muslim, p. 1-3.

45 Ibid.

46 It was worth mentioning that one of them was Dutch in citizenship. He was Rahmat Zitter. Interview with A. Hambali Maksum, 17 May 2008, The Hague.

47 See: Muhamad Hisyam, Persatuan, p. 23. 
Indonesian youths frequently gathered. Therefore, it was called their youth's headquarters. ${ }^{48}$ Thirteen youths participated in the meeting, which commenced at midnight. ${ }^{49}$ Some of them resided in Rotterdam and The Hague, the Netherlands, and some others in Germany. ${ }^{50}$ They proposed critical ideas that should be considered before establishing a new Muslim organization, including ideas on Dutch rules on Muslim organizations, the possibility of founding a new Muslim organization, current Muslim organizations, and the connection to PPI Perhimpunan Pelajar Indonesia]. At the end, they came to an agreement that the effort to found an organization for Muslim youths should move ahead. The meeting came to an end at 3:00 a.m. ${ }^{51}$

Then, in the beginning of February 1971, a second meeting was held, resulting in an agreement on the formation of a commission for the design and composition of the statutes and bylaws of the new organization. ${ }^{52}$ This commission consisted of four people, Moh. Sayuti Suhaib, Moh. Chaeron, Rahmat Zitter, who were living in the Netherlands, and Abdul Wahid Kadungga, who resided in Germany. ${ }^{53}$ It should be mentioned that the number of participants was smaller than that of the first meeting. In this meeting, Kadungga was one of the representatives residing in Germany. It is also worth mentioning that from the Netherlands, only some of the participants could attend the second gathering. ${ }^{54}$ Nevertheless, the creation of the commission indicates that the conditions did not undermine their goals and efforts to create a vehicle for their da'wa activities.

Having working hard from February to March, the commission, assisted by a new member, Ahmad Hambali Maksum, finally accomplished their task, preparing the design and composition of the statutes and

48 Read: DPP PPME, Laporan, 1973.

49 Exactly at 12 p.m. See: DPP PPME, Laporan, 1973.

${ }^{50}$ Such as Kadunngga, Ali Baba, and A. Doni. See: Muhamad Hisyam, Persatuan..., p. 23.

51 DPP PPME, Laporan, 1973.

52 Ibid.

53 Muhammad Hisyam, Persatuan, p. 24

54 See: DPP PPME, Laporan, 1973. 
bylaws $^{55}$ for a new Muslim organization. On 11 April 1971, the last meeting was held, commencing at 12:00 p.m. ${ }^{56}$ The gathering, consisting of twenty one participants, agreed on a name 'PPME', the abbreviation for Persatuan Pemuda Muslim se-Eropa (Young Muslim Association in Europe), for their new organization. ${ }^{57}$ In addition to the chosen name, there were, in fact, other choices put forward such as Gerakan Pemuda Islam Eropa (Islamic Youth Movement in Europe), and Organisasi Pemuda Islam Eropa (Islamic Youth Organization in Europe). ${ }^{58}$ It was said that the reason for the chosen name was due to the first word 'Persatuan', which applied to the necessity of the moment. Besides, the choice, especially related to the word "Eropa", accommodated a Dutch founder, Rachmat Zitter ${ }^{59}$ whose house was frequently used for gatherings of Indonesian youths, and the citizenship of another founder, Amir al-Hajri, from the Republic of South Yaman. ${ }^{60}$ Therefore, the choice could not be disassociated from their life in Europe, rather than Indonesia. This historic gathering ended with the declaration of its establishment as follows:

\section{"Bismillahirrahmanirrabim"}

\section{Pernyataan}

Kami yang hadir dalam pertemuan yang diadakan pada saat dan tempat ini, menyatakan berdirinya organisasi yang bernama Persatuan Pemuda Muslim se Eropah. ${ }^{61}$

Barenstraat 4, Den Haag, 12/4-71". 62

55 The writer wished to depict them in another section discussing the nature and objectives of PPME.

56 A. Hambali Maksum was, even though he was not a member of the commission, also involved in finishing the composition of preparatory statute and bylaws. Read: DPP PPME, Laporan 1973.

57 See: Muhamad Hisyam, Persatuan, p. 24.

58 Read: DPP PPME, Laporan, 1973.

59 Interview with A. Hambali M, 17 May 2008.

60 Interview with Saleh al-Nahdi, 12 August 2008.

${ }^{61}$ In Hisyam's work of 1996, the word Eropah was replaced with Eropa. Nonetheless, although they were different in spelling, they had the same meaning. This word 'Eropah' was used before the Ejaan Yang Disempurnakan (EYD, the Perfected Indonesian Alphabet) of 1972.

62 DPP PPME, Laporan. 
In addition to the twenty one participants ${ }^{63}$ in the last meeting, there were two other important figures who could not take part. One of them was Moch. Chaeron. He was an active and creative figure in this new organization from the very beginning. He was both a founder and a member of the commission for the statutes and bylaws, and the creator of the logo for the organization. He was absent from the meeting due to his new job in Groningen, Netherlands. The other person not present was the owner of the Indonesian youth's headquarters, and a member of the board in charge of welfare affairs in the new organization, Rachmat Zitter, who was in Brussels, Belgium. ${ }^{64}$

The elected chair person of the new Muslim organization was Kadungga, who just passed away in December $2009,{ }^{65}$ a son in law of Kahar Muzakar, a key figure of the Darul Islam movement in South Sulawesi. ${ }^{66}$ The process of election mirrored their understanding of democracy. Before the election, Kadungga demonstrated his leadership abilities in organizing the voting of the participants in the election, beginning with proposing the names of certain figures, ${ }^{67}$ considered capable of running the new organization. The candidates were Abdurrahman Wahid - who passed away in December 2009 -, Moh. Suyuti Suhaib, A. Hambali Maksum, Yus Muchtar and Abdul Wahid Kadungga. According to the rules of the election, the voices of the founders were classified in three methods i.e. the first was direct election; the second was to elect formateur [s]; and the third was to elect the semi-formateur [s].

${ }^{63}$ They were 1). M. Sayuti Suhaib 2). Abdul Wahid Kadungga 3). Imam 4). Ozir M. Isa 5). Rusli Bena 6). A. Hambali Maksum 7). Ujang HS. 8). Azmihardi S. 9). T. Razali 10). Husni Basuni 11). Ali Khalik 12). S. Abidin 13). I. Idram 14). M. Rais Mustafa 15). A. Muiz 16). Suwardi 17). Abdurrahman Wahid 18). Moh. Syukur 19). Machfud Muchtar (Yus) 20). Moh. Amir and 21). Ade Baharuddin. DPP PPME, See: DPP PPME, Laporan, 1973.

${ }^{64}$ Ibid.

65 Ibid.

${ }^{66}$ Interview with A. Hambali M., 17 May 2008. Also read: Muhamad Hisyam, Persatuan, p. 24-25

${ }^{67}$ It was mentioned that Abdurrahman Wahid was reluctant to run the new organization because he desired to return to Indonesia. See: Muhammad Hisyam, Persatuan, p. 25. Nonetheless, he had no objection to be involved in the discussion about figures for the board of the new organization. 
They came to an agreement of choosing the third way, whose rules were that if a figure gained more votes than the others he would automatically become both the leader of the formateurs and of the new organization. Furthermore, leading figures who received votes but not enough to win, were not obliged, but possibly became the elected leader's partners serving to design and position certain figures as the board of the new organization. After each participant voted by putting the desired name on a ballot, the result was that fourteen votes went to Kadungga, ten to Wahid, eight to Suhaib, seven to Muchtar and three to Hambali. Having elected its leader, the participants agreed that Wahid and Suhaib should become the partners of Kadungga in order to form the board of the new organization. ${ }^{6}$

\section{Natures and Objectives: Passing over Indonesian Nationalism}

To identify the nature and objectives of PPME, it is not only important to consider the statutes and bylaws but also the nationalities of the members, and their socio-cultural and religious background. Its official statute proclaimed that the sole basis of its struggle was "Islam" not "Indonesian Nationalism" ${ }^{69}$ In reaching this decision, there were disagreements among its founders.

There were at least two conditions behind the desire for the new organization to be based upon "Indonesian Nationalism". The first was the spirit of "Indonesian Nationalism" that reached its peak with the revolt of Partai Kommunis Indonesia (PKI). The other was that the already existing Indonesian organizations had made use of the label "Indonesia", such as Perhimpunan Pelajar Indonesia ${ }^{70}$ (PPI) and

68 DPP PPME, Laporan, 1973.

${ }^{69}$ For this fact the author preferred to use this source: The State Secretary of Justice, Bijvogsel van de Nederlandse Staatscourant, dated 14 August 1974 instead of other versions of PPME's statute and bylaws. The reason for this choice is that its official statute and bylaws of PPME existed in the former version. The significant difference is that in the Dutch version, according to article 1: verse 2 of its statute, its existence was restricted for 29 years, and could be prolonged when it remained important. In the other versions the restriction was, however, absent. Hisyam's work did not mention these variant documents.

70 In Hisyam's work (1996, p. 25) the abbreviation of PPI meant Persatuan Pelajar Indonesia. This is mistaken. The right was Perbimpunan Pelajar Indonesia. This cor- 
Persekutuan Kristen Indonesia (Perki). ${ }^{71}$

Despite the strong push for nationalism, the final agreement excluded the words "Indonesian Nationalism" in the statute of PPME of 1971. This exclusion can be easily understood if the goals of the association are considered. It was founded to perform Islamic teaching through Islamic propagation, creating free-networking and conducting joint activities, and performing academic, cultural and social activities. ${ }^{72}$ These goals and endeavors strongly suggested that political activities lay outside the scope of the organization, that it was autonomous, with no affiliation to either the Indonesian or Dutch governments. This basis also signified a desire to pass over ethnic and nationality boundaries. This would be in line with the following arguments for the exclusion. The new organization could, without such nationalism, reach a broader geographical area with more members, not preventing any Muslim from being a member or participant. Islam, as the basis of struggle, then, possessed wider reaching values than nationalism. ${ }^{73}$ Another salient argument related to the word "Eropa", which accommodated the nationality of a founder of the association who was not Indonesian but Dutch, in spite of having Indonesian blood from one of his grandparents. He was R. Zittter, who merited special attention due to his generosity in terms of providing a place for the gatherings of the founders. ${ }^{74}$ This also accommodated the nationality of Al-Hajri, as a Yamani not Indonesian.

rection was based upon information the interview with the secretary general of the PPI, Christian, when attending the Stuned Day held in Indonesian Embassy on 31 May 2008, and with the activist of the first generation of PPME, A. Hambali Maksum in his apartment, 17 May 2008, the Hague..

71 See: Muhamad Hisyam, Persatuan, p. 25

72 See: Article 4: verse 1,2 and 3. The State Secretary of Justice, Bijvogsel van, dated 14 August 1974. See also: Article 4 verse 3, in DPP PPME, The Statute of PPME (The Hague: PPME, 1976 and 1979).

73 See: Muhamad Hisyam, Persatuan, p. 26.

74 Interview with A. Hambali M., 17 May 2008 
In its bylaws, ${ }^{75}$ the logo of PPME ${ }^{76}$ created in 1972 and officially recognized in $1973,{ }^{77}$ was a crescent facing the European continent, framed in a circle. This circle symbolized the strong commitment of the Muslim youth in performing and presenting Islamic teaching in their daily life. The crescent represented the Islamic teaching originating from the Middle East and frequently discussed by intellectuals in Europe. The European continent was the target for their da'wa activities. ${ }^{78}$

This logo had colours with specific meaning. White for the crescent signified the holy and perfect Islamic teaching. The light blue for the European continent signified the inhabitants starting to accept the truth of Islam. The last colour, dark blue, aimed to depict the high standard of morality of those who spread Islam on the continent. ${ }^{79}$

PPME's founders came from various islands such as Java, Sumatra, Celebes, Moluccas, Borneo, etc. The diversity was not merely in ethnicity but also in nationality. As mentioned above, R. Zitter was Dutch, ${ }^{80}$ and Amir al-Hajriy was Yamani. Recently, there have been Dutch members actively participating in branches of PPME, especially in The Hague, Amsterdam, Rotterdam, and Heemskerk. ${ }^{81}$ In addition to those holding Dutch citizenship, other members hold citizenship from Malaysia and Philippines. ${ }^{82}$ Another group that cannot be neglected are those coming

75 DPP PPME, The Bylaws of PPME, The Hague: PPME, 1979.

76 The logo of PPME was created by Mochammad Chaeron. This logo had been agreed on in 1973 by the participants of the General Meeting, the highest level gathering attended by the delegates of regional and branches executive committees of PPME. Interview with the wife of late M. Chaeron, S. Atikah Z., 11 August 2008 at 20.30, The Hague. The similar recognition was delivered by Kadungga, a founder and the first chairperson of PPME, also recognized him as its creator. Read: DPP PPME, Laporan, 1973.

77 During the first general meeting held on August 25-26, 1973 in Indonesian Embassy, The Hague. Read: Ibid.

78 See: Muhammad Hisyam, Persatuan, p. 27.

79 See: Ibid., p. 28

80 Interview with A. Hambali M, 17 May 2008.

81 Interview by phone with Listi, the Chairperson of PPME Heemskerk, Wednesday 2 July 2008 at 20.32 .

82 Interview with Ruud Pourchez, the Chairperson of PPME Rotterdam, Friday 27 July 2008, at 15.00, Rotterdam. 
from Suriname. This group was Javanese in origin but mostly Dutch in nationality. ${ }^{83}$ Last but not least, there were those who were of Arab descent, ${ }^{84}$ either holding Indonesian nationality or having some historical connection with Indonesia.

Pertaining to this diversity, what Shadid and Koningsveld claimed, that PPME belonged to the Indonesian community, ${ }^{85}$ was not fully mistaken. This was due to the fact that the majority of its members were, at the time, Indonesian. Nonetheless, members having other nationalities have recently multiplied in number.

This diversity was the logical consequence of PPME's basis in Islam, welcoming Muslims, regardless of their nationality, to be its members and participants. As a result, on the one hand, this diversity was an opportunity for building the imagined Islamic umma. On the other hand, to a great extent, it would be a challenge for its board, in particular, in making policies and strategies, and programs for their members who were diverse in nationalities and languages, and in playing the social, cultural and institutional roles of PPME.

Regarding the objectives of the new association, with its nonpolitical orientation and its political independence, this association could not be easily classified according to the categories of Waardenburg. It could not, firstly, be considered "a more spiritual association," the first category, which was concerned with the spiritual well-being of its members and providing better knowledge of religion, tending to keep a distance from politics and the state, ${ }^{86}$ such as the Jamā'at al-Tabligh founded in Northern India. ${ }^{87}$ This was because PPME, also, intended to

83 Their examples were Riboet Kasan, a member of the board of PPME Amsterdam, and Amin Dijo, a member of PPME al-Ikhlash Amsterdam.

84 Their examples were Aziz Balbaid, the advisor and central figure of PPME Amsterdam, and Amir al-Hajri, a person attending the declaration of its establishment.

85 Shadid and Koningsveld, "Institutionalization and Integration of Islam in the Netherlands", in W.A.R. Shadid and P.S. van Koningsveld (Eds.), The Integration of Islam and Hinduism in Western Europe (Kampen: Kok Pharos, 1991), p. 100-101.

86 J.D.J. Waardenburg, "Muslim Association and Officials Bodies in Some European Countries", in Ibid, p. 32.

87 F. Dassetto and G. Nonneman, "Islam in Belgium and The Netherlands: towards a Typology of 'Transplated' Islam”, in Gernad Nonneman et. al., Muslim, p. 206-207. 
improve the social and cultural conditions of its members. Nevertheless, this new association could be categorized into his second category ${ }^{88}$ with some modification, that is, the absence of loyalty to Indonesian or Dutch governments. In addition, to some extent, it functioned as the vehicle for some of its founders' dissatisfaction ${ }^{89}$ with the restrictive policies of the Indonesian government, in connection with the freedom to perform da'wa activities. This function was part of the characteristics of Waardenburg's third categorization of Muslim organizations in Western Europe. Therefore, PPME cannot be easily categorized according to the first, second or third classification, but rather some combination.

In addition to ethnic and national diversity, its members were heterogeneous in profession. As a matter of fact, early in its development, the main actors of this new association were students and alumni of universities. This changed as the founders grew older and some of them passed away. Recently, its members and participants have included officers, ${ }^{90}$ unskilled labourers, ${ }^{91}$ business people, ${ }^{92}$ and pensioners. ${ }^{93}$ In addition, this organization welcomed students to enroll in this socio-

88 This second classification was directed to associations that intended to improve "the social, cultural and educational conditions or their members and Muslims at large, at least those from the same country of origin". This kind conditioned the loyalty to "the existing state of affairs in the country of origin and of course to the state in which they live"; J.D.J. Waardenburg, "Muslim Association and Officials Bodies in Some European Countries", in Shadid and Koningsveld, The Integration, p. 32.

89 His third category was aimed at organizations which had similar concerns to those of the second one with dissatisfactory expression with "public affairs and government policies in their countries of origin"; Ibid.

90 The examples for this group were William Satriaputra de Weerd, the officer of Korean Company, Samsung, and Ruud Pourchez, the officer of Akzo Nobel were some examples

91 Those who worked without the necessity of using a high level of skills such as cleaning service, waiters, etc.

92 Budi Santoso, the central figure of PPME al-Ikhlash Amsterdam and the owner of Indonesian Restaurant, Aziz Balbaid, the importer of foods, and the like, were some examples.

93 A. Hambali M, the pensioner of Dutch insurance company, S. Atikah Z, the pensioner of the SIN and Riboet Kasan, the Pensioner of Teken en Ontwerp Buro: Marilu Engineering are the examples. 
religious organization, as well. ${ }^{94}$ Registered students were, in general, the family members of PPME members. ${ }^{95}$ Nonetheless, it remains possible for a student to participate and register him or herself as a member despite having no familial relation with the families affiliated to PPME. ${ }^{96}$ The statement of Shadid and Van Koningsveld that students were the largest group in prayer-halls used by $\mathrm{PPME}^{97}$ seems to be incorrect. From the outset, this new organization was not aimed at Indonesian students temporarily residing in the Netherlands but Indonesian Muslims who had resided in the country. ${ }^{98}$

Lastly, the religious background of its members and participants will be described. Since the establishment of the association, the socioreligious backgrounds of members and participants have never played a main role in developing and expanding it. ${ }^{99}$ Traditionalists and modernists ${ }^{100}$ were hand in hand in running this new organization. Recently, its members and participants have even included 'statistical' Muslims. ${ }^{101}$ Therefore, affiliation to NU, Muhammadiyah, or other Islamic organizations, was never the main focus of PPME. Furthermore, even those who had no religious knowledge or background could be active members. In this way, they maintained their unity from 1971 till the end of 2005, when the

94 Interview with Ruud Pourchez, 27 July 2008.

95 Interview with William Satriaputra de Weerd, the chairperson of PPME the Netherlands, 25 May 2008, Rotterdam.

96 Interview with Ruud Pourchez, 27 July 2008.

97 Shadid and Koningsveld, "Institutionalization and Integration of Islam in the Netherlands", in W.A.R. Shadid and P.S. van Koningsveld (Eds.), The Integration, p. 100-101.

98 Interview with A. Hambali M., 17 May 2008, The Hague.

99 Ibid., and interview with William Satriaputra de Weerd, 25 May 2008, Rotterdam.

${ }^{100}$ Interview with A. Hambali M., 17 May 2008, The Hague.

101 This term was aimed at those Muslims who were not santri and not devout. Read: C. van Dijk, "Communist Muslims in the Dutch East Indies", in C. van Dijk and A. H. de Groot (eds.), State and Islam (Leiden: CNWS, 1995), p.78. Furthermore, the santri could mean the fanatic Muslims "who stress a strict adherence to religious rules; read: Kees van Dijk, "Dakwah and Indigenous Culutre: the Dissemination of Islam", in B. Arps et. al, (eds.), Bijdragen, No. 154.2 (Leiden: KITLV,1998), p. 222. Nonetheless, the santri could also, here, mean Muslims who had learned Islamic knowledge in the pesantren. 
conflict of religious orientation reached its peak, bringing about a split in PPME Amsterdam into two congregations, the PPME Amsterdam and the PPME al-Ikhlash Amsterdam.

From the outset, the main actors running the association were mostly alumni and students. This phenomenon could have endured up to now. Most of its board members came from the middle class and were graduates of universities or higher education institutions, and this continues to be the leading group in it, without mosques or halls for worship. Shadid's and Koningsveld's classification of the association as a grass roots organization for Indonesian Moluccans in the Netherlands, having local autonomous mosques, ${ }^{102}$ seems to be true of PPME's congregations only in terms of economics, not education.

The germ of world youth culture had been embraced by the founders of this new organization. The characteristics of its mission and logo, passing over nationality, are the evidence. Therefore, international activity was extremely likely. Furthermore, PPME, since its establishment, set out to be an independent socio-religious organization with diverse backgrounds and not an instrument of a nation-state foreign policy. These characteristics seem to be part of the nature of a world youth movement. ${ }^{103}$ These however applied only till they reached the age of 35. Afterwards, they could no longer be considered youth.

\section{E. The Re-structure and the Expansion of PPME: against Political-Orientation}

Less than two years, exactly 20 months, after the establishment of PPME in The Netherlands, on 13 January 1973 Indonesian Muslims in Germany were motivated to establish their own PPME in the country. Therefore, there existed two PPMEs. Organizationally, their status

${ }^{102}$ When elaborating Muslim organizations focusing on one or more ethnic communities as a whole they classified them in four categories, namely "organizations which mainly resort under the authority of the governments of one of the countries of origin, organizations depending upon the governments of various Muslim countries, organizations which are attached to internationally organized religious movements of a specific confessional nature and which are independent of foreign governments, and grass root level organizations"; W.A.R. Shadid and P.S. van Konigsveld, Religious Freedom and the Position of Islam in Western Europe (Kampen: Kok Pharos, 1995), p. 50.

${ }^{103}$ Read: William D. Angel, Youth, p. 3-8. 
necessitated a re-structure in such a way that the position of each was lucid. No less importance was also their structural development over time at which their expansion can be clearly identified.

\section{The Netherlands}

Having been formed in 1971 in The Hague, the board of PPME was later renamed, Dewan Pimpinan Pusat (DPP, the Central Executive Committee) due to the presence of the board of PPME in Germany. Then, in 1974 the board of Dewan Pengurus Wilayah (DPW, the Regional Executive Committee) of the Netherlands was formed, and was led by M. Surya Alinegara. ${ }^{104} \mathrm{DPW}$, furthermore, founded branches in Amsterdam, The Hague, Rotterdam, Heemskerk and Breda-Tilburg. In 1975, branches of PPME in The Hague, Rotterdam, and Amsterdam were founded. ${ }^{105}$ These three branches of PPME played significant roles in developing this organization.

The Hague was the city in which the declaration of the establishment of PPME was made. In addition, PPME in the Hague had a strong relationship with the Indonesian embassy. In 1997, its active members included 83 families. ${ }^{106}$ By 2008, however, the number of its members was not clear. ${ }^{107}$

Rotterdam was the first headquarter which produced and distributed brochures and a bulletin, entitled al-Falah. It was also this branch that experienced a split in the mid-1980s, due to different orientations among its members i.e. political versus non-political orientation. ${ }^{108}$ The PPME branch in this city was under the leadership of Hisyam Pula, alias Abu Jihad, who pushed to make the organization more politically oriented, but

${ }^{104}$ See: Muhamad Hisyam, Persatuan, p. 29-30

105 http:/ / www.ppme.nl/Nederland/Geschied.htm, accessed on 20 July 2008, at 19.02 p.m.

${ }^{106}$ DPC PPME, Laporan Pertanggungjawaban PPME Cabang Den Haag 1996-1997 (The Hague: PPME, December 1997), p. 14.

107 The chairperson of PPME The Hague branch, Aaman Sulchan estimated that the number of its member has recently reached more than active seventies families. Interview with Aaman Sulchan, 17 May 2008, in Al-Hikmah Mosque, The Hague.

${ }^{108}$ DPW PPME the Netherlands, Laporan Umum Pengurus PPME Wil. Nederland 1984-1986 (The Hague: PPME, 1986), p. 23. 
was not recognized by the DPW of the Netherlands due to his absence, though invited, from the resolution gathering held by the DPW. As a result, the DPW recognized the branch under the leadership of Tjen A. Kwoei, who kept it away from political issues. This leader attended the gathering. ${ }^{109}$ In this city, PPME's members in 2008 included only sixty families. ${ }^{110}$ Nevertheless, this branch has frequently conducted joint activities, particularly, with people from Surinam. ${ }^{111}$

PPME Amsterdam was considered to be a well-developed branch before internal conflict led to disunity at the end of 2005. Its members' strong commitment and independence in developing their PPME is worth noting. This attitude led them to establishing their own place for worship and socio-cultural activities in 2005. ${ }^{112}$ In spite of internal conflict ${ }^{113}$ the socio-religious commitment and self-help of members of the PPME Amsterdam branch -not PPME al-Ikblash Amsterdamincreased. Evidence of this can be seen in an electronic web-based da'wa program directly delivered by their Indonesian ulama both from Saudi Arabia and Indonesia. In 2008, its member included 268 families. ${ }^{114}$

On 18 April 1998, the formation of a new branch of PPME in Heemskerk took place. A small group who had been interested in Islamic subjects led to the emergence of this branch. This group frequently worked together before becoming a branch. ${ }^{115}$ This branch, in 2008, included 15 families. It was run by a female leader. This was due to the fact that, from the outset, most of its members were Indonesian wives whose husbands were Dutch. Before 1988, when they decided to join

${ }^{109}$ DPW PPME the Netherlands, Laporan Pertanggungjawaban Program Kerja PPME Nederland 1992-1994 (The Hague: PPME, 1994), p. 7.

${ }^{110}$ Interview with Ruud Pourchez, 27 July 2008, Rotterdam.

${ }^{111}$ DPC PPME, Proposal for the Construction of a Mosque for the Indonesian Community in the Netherlands (Rotterdam) (Rotterdam: PPME, January 2004), p. 12.

112 http:/ / achmad-supardi.blogspot.com/2005_10_01archive.html, quoted at 11.59 of 21 July 2008. The writer was a journalist of the newspaper "Rakyat Merdeka".

${ }^{113}$ One was called PPME Amsterdam Branch and the other was called PPME al-Ikhlas Amsterdam

${ }^{114}$ Interview with Aziz Balbaid, 28 July 2008, Amsterdam.

115 DPW PPME the Netherlands, Laporan Pertanggungjawaban Program Kerja PPME Wilayah Nederland Periode 1997-1999 (The Hague: PPME, Juni 2000), p. 6. 
PPME, the wives had formed a group to discuss Islamic subjects meeting in their apartments or houses. Their husbands, who were mostly converts, usually drove their wives to the place in which the activity was held. Before joining PPME, the number of families that joined the group had reached 40 . Nonetheless, this new branch has recently included a male group separate from the female group, due to different languages being used, with Indonesian for the females and Dutch for the males. Their activities have been held monthly in a leased hall. In addition to activities for adults, there have been religious activities for their children. ${ }^{116}$

On 30 December 2005, a branch of PPME called al-Ikhlash was founded in Amsterdam. ${ }^{117}$ The number of members of this branch recently reached 125 families. ${ }^{118}$ The members of this new branch had previously been part of the PPME Amsterdam branch. This new branch was formed because of different religious understandings among the members of PPME Amsterdam branch regarding activities such as reciting the süra yasis and conducting the tradition of tablilan for certain occasions. This new branch included such activities, conducting them in the apartments or houses of members. The differing views between the two sides reached a critical point when the PPME Amsterdam branch raised money to buy a building for their religious and socio-cultural activities. All members donated money, and with donations from other sources, the group was able to buy the building. Because of their financial contributions, the holders of the tradition, the PPME al-Ikhlash, wanted to move their activities from their own houses and apartments, into the new building. However, the other side, those who did not conduct the aforesaid traditions, argued that the activities which could be performed in the new building should be agreed to by all. ${ }^{119}$ One of them pointed out that such traditions should not be performed in the new building because

${ }^{116}$ Interview by phone with Lusti, the chairperson of PPME Branch of Heemskerk, 2 July 2008.

117 Siti Fatimah, Laporan Notulen Rapat ke-Empat Pengurus Majlis Drikir (Amsterdam: PPME Majlis Dzikir), 31 December 2005.

${ }^{118}$ DPC PPME al-Ikhlash, PPME al-Ikblash Amsterdam Ledenlijst (Amsterdam: PPME, n.d).

${ }^{119}$ DPW PPME Nederland, Keputusan PPME Wilayah Nederland, No. 2/ PPMENL/XII/2005 (The Hague: DPW PPMW, 18 December 2005), appendix 2. 
not all members wanted to participate in such activities. ${ }^{120}$ Another said that the traditions should continue to be performed in the homes of participants because there were differing views regarding the Islamic jurisdictional foundations of the activities. ${ }^{121}$ The boards of Regional PPME in the Netherlands finally came to the decision that the two sides should be divorced on the basis of the fact that the two groups were firm in their points of view, and could not exist under one umbrella, the PPME Amsterdam branch. ${ }^{122}$

Lastly, in 2005, ${ }^{123}$ the PPME branch of Breda-Tilburg was founded. Since the year 2000, reciting Quranic verses, the süra yasin, and the tablilan for families that had experienced calamity, had been occurring. While the registered number of families was around 35, about 15 to 20 families actively participated in programs held by this branch in the houses or apartments of members. ${ }^{124}$

\section{Germany}

The establishment of PPME in the Netherlands motivated Indonesian Muslim youths in Germany to found their own PPME. It is important to note that the youths were students, making the situation very different from that of the organization in the Netherlands, whose founders were, for the most part, no longer students. ${ }^{125}$

On 19 January 1973, this new PPME was established in Otto Eger Heim, Giessen, Germany, and was led by Rasyid Suparwata, who up to 2008, led the Pimpinan Cabang Istimewa Muhammadiyah (PCIM-the Special Branch of Muhammadiyah). This new organization was witnessed by fourteen youths who released the following statement:

${ }^{120}$ Interview with Riboet Kasan, a member of PPME Amsterdam's board, 10 May 2008, Amsterdam.

${ }^{121}$ Interview with Aziz Balbaid, 28 May 2008, Amsterdam.

${ }^{122}$ DPW PPME Nederland, Keputusan PPME Wilayah Nederland, No. 2/ PPMENL/XII/2005 (The Hague: DPW PPMW, 18 December 2005), appendix 1.

123 http:/ / mww.ppme.nl/Nederland/Geschied.htm, accessed on 20 July 2008 at 19.02 p.m

${ }^{124}$ Interview by phone with Hansyah, the chairperson of PPME Branch of BredaTilburg, 30 June 2008.

125 See: Muhamad Hisyam, Persatuan, p. 26 


\section{"Bismillabirrahmanirrabim,}

Kami yang bertanda tangan di bawah ini, pendukung perintis pembentukan organisasi Persatuan Pemuda Muslim se-Eropah Jerman Barat, menyatakan kesediaan dan tanggung jawab terhadap kelangsungan hidup organisasi ini sejak didirikan pada tanggal 19 Januari 1973 atau 9 Dzul Hijjah 1392 H, di Otto Eger Heim, Glessen. Semoga kami tetap beriman, Islam dan mudah-mudahan Allah SWT melindungi organisasi ini serta kami dalam melaksanakan tugas kewajiban sebagai Muslim[,] amien".126

The founders of the PPME in Germany wished, not merely to found their own PPME, but also to expand it. This can be seen in their choice of appointing coordinators from different cities, such as Marzuan Umar from Giessen, Rasjid Widodo from Darmstadt and Naunas Salam from Offenbach. This concern was not as important for their brothers in Islam in the Netherlands, who focused more on strengthening their unity. The formation of the division of art and welfare in the PPME the Netherlands was proof of this. Through this division, various socioreligious needs of its members could be accommodated.

On 21 December 1975, with the DPP and DPW of the Netherlands, the PPME's board in Germany became another DPW, in addition to those of the Netherlands. For this new DPW, Suparwata remained leader. ${ }^{127}$ In Germany, in between 1973-1976, branches were formed in Dortmund, Frankfurt, Darmstad, Offenbach, Giessen, Berlin ${ }^{128}$ and Heidelberg. ${ }^{129}$ By 1982, there were branches in Clausthal and Bochum, and members in Hamburg and Bonn, as well. ${ }^{130}$ The existence of these branches followed the spirit of expansion.

The DPP of PPME, previously headquartered in the Netherlands, moved to Germany in 1979. This was because S.A. Rangkuti lived in Germany. It is worth mentioning that for almost ten years there was unity between PPME of the Netherlands and Germany. However, their

\footnotetext{
${ }^{126}$ Read: DPP PPME, Laporan, 1973.

${ }^{127}$ Read: DPP PPME, Laporan, 1976, p. 4-5.

${ }^{128}$ See: Muhamad Hisyam, Persatuan, p. 29-30.

${ }^{129}$ DPW PPME Germany, Laporan Kerja DPW PPME (Darmstadt: PPME, July 1976), p. 2.

${ }^{130}$ DPP PPME, Daftar Peserta Musyawarah Umum IV (The Hague: PPME, November 1982).
} 
differences in nature and orientation ${ }^{131}$ created divisions and finally led to their disunity. This suggested that their commitment for the shi 'ar of Islam [in Europe] was neglected. ${ }^{132}$

This disunity led to the non-functioning of the DPP since 1982. There were several reasons for this. First, the policies and strategies of PPME were in need of clarity. Secondly, its statutes and bylaws needed revision to accommodate the needs of branches. ${ }^{133}$

Then, in September 1992, the DPP was revived, due to the efforts of the DPW of the Netherlands. The elected leader in the Fifth General Meeting in Rotterdam was M. Zubaidi, from PPME of Germany. ${ }^{134}$ However, five months later after the re-starting the DPP, Zubaidi, the elected chairperson, crossed out the words 'Berdasarkan Pancasila', written by Munawir Syadzali, the former minister of the Republic of Indonesia in the preface of Al-Qur'an dan Terjemabannya (the Quran and Its Translation) given by the government of Saudi Arabia. ${ }^{135}$ According to the DPW of the Netherlands, this action was not in line with the statute of PPME article 3 stating that PPME was an organization for education and da'wa, and was independent. It was not a political organization. ${ }^{136}$ The difference in vision between PPME the Netherlands and Germany brought about their separation, except for a few individuals who shared a similar vision to that of their friends in the Netherlands. ${ }^{137}$ Due to this difference,

${ }^{131}$ The proponents of PPME in the Netherlands, who were mostly no longer students, had firmly run this new organization for da'wa-oriented activities in Europe. This differed from the wishes of their fellow Muslims living in Germany, who wanted it to respond to the political situation in Indonesia. This difference in orientation seems to have been the result of differences in status, with those in Germany being students and having temporary residence, while those in the Netherlands were not students and residing longer.

${ }^{132}$ Muhammad Hisyam, Persatuan, p. 34-35.

${ }^{133}$ DPW PPME, Ikrar Musyawarah Wilayah Luar Biasa 1982 (Germany: PPME, November 1982).

${ }^{134}$ DPW the Netherlands, Laporan Pertanggungjawaban Program Kerja PPME Periode 1992-1994 (The Hague: PPME, November 1994), p. 6-7.

135 Ibid., p. 14-15.

${ }^{136}$ DPW the Netherlands, Surat untuk M. Zubaidi, No. OX/KWN/01/93 dated 08-01-1993 (The Netherlands: PPME, 1993).

${ }^{137}$ Muhammad Hisyam, Persatuan, p. 38-39. 
since the 1990s, there have been no activities of PPME in Germany. It is true that some activists of PPME of Germany can be found in the country. However, their number is not sufficient to re-activate PPME. The absence of their boards, whose members had returned to Indonesia after finishing their study, was the main reason for the dissolution of PPME in Germany. ${ }^{138}$

\section{Other Countries}

The efforts to expand the new organization drew the attention of Indonesian youths in European countries such as in Great Britain, France, Sweden, and Belgium, through personal networks, irregular visits, and attending scientific discussions. However, these efforts were generally not fruitful.

It was claimed that personal contacts had been made in various cities in Europe such as in Brussels, Helsinki, Paris, and London. ${ }^{139}$ However, PPME was never founded in these countries. ${ }^{140}$ In fact, there was a member of PPME that resided in London, M. Fadhol Arofah. He was an active and critical member of PPME during the 1970s. ${ }^{141}$ Yet, establishing contact persons or representatives in these countries was never seriously discussed. This was due to the fact that no branches of PPME were established outside of the Netherlands and Germany.

\section{F. The Status of PPME and Its Activities: Progressive Muslims}

The following are the salient activities conducted by PPME's central, regional and branches boards since its establishment in 1971. These activities can serve to measure its presence and development both prior to and after gaining official recognition from the Dutch government.

${ }^{138}$ Interview with A. Hambali M, 17 May 2008 and William Satriaputra de Weerd, 25 May 2008.

139 See: Muhamad Hisyam, Persatuan, p. 29-30.

${ }^{140}$ DPP PPME, Laporan, 1976, p. 5.

${ }^{141}$ One of his critical thoughts delivered in General Meeting II could be found on his short paper entitled Sumbangan Pemikiran kepada Musyawarab Umum PPME II. He emphasized that the limited time of its board should not be exposed as a reason for its stagnancy and the lack of its cooperation with other sides. Maryadie, M F A, Sumbangan Pemikiran kepada Musyawarah Umum PPME II (London, 21 July 1976), p. 1-3. 
Therefore, through these activities, its dynamism can also be seen.

\section{Prior to May 1974}

A strategic step taken by the board of PPME was to propose the legalization of the new organization to the Dutch government. This step required the assessment of the principles the founders held regarding their socio-religious commitment, idealism, and volunteerism. In this regard, they had to satisfy legal and organizational requirements, such as changing the content of its statutes in connection with article 1: verse 2 about the time limitation of the existence of PPME, ${ }^{142}$ the replacement of its functionaries who did not possess a permit for permanent residence in the Netherlands, ${ }^{143}$ and the formation of a team authorized to execute these tasks.

On the basis of a letter no. 004/PPME/SEK/73, a team responsible for these tasks was formed. This team, headed by Jus M. Muchtar, had to make ready the necessary documents, and to write and propose a letter requesting legal recognition of PPME from the Dutch government. ${ }^{144}$ The team, then, started writing the letter directed to the government. ${ }^{145}$

Having delivered the letter to the government in February 1973, the response came two months later. The government required a meeting with the board of PPME to gain clarification on article 1: verse 2. The Ministry of Justice required a clear idea of how long PPME would exist. ${ }^{146}$ For this, they chose twenty nine years as the limit, though this could be extended as long as necessary. ${ }^{147}$

${ }^{142}$ On Mochamad Chaeron's notes it was written that the words 'voor onbepalde tijd' in article 1: verse 2 of PPME's statute should be changed. The end of its existence should be determined.

143 Interview with A. Hambali Maksum, 30 June 2008, The Hague.

144 See: Muhamad Hisyam, Persatuan, p. 30-31.

145 DPP PPME, Laporan ..,1973.

${ }^{146}$ Interview with A. Hambali M, 30 June 2008.

${ }^{147}$ The 29 years as the time limitation was as the result of initiative of the founders. Interview with A. Hambali M., 30 June 2008, The Hague. 
Another task pertained to article 4: verse 1 on the words: 'Performing Islamic da'wa. ${ }^{148}$ These words might be considered clear enough if it was proposed to Muslim governments, but not for the Dutch government. Having clarified that the phrase meant speaking and writing about Islam in PPME gatherings and bulletins, the Dutch government was satisfied and no longer raised any objections to the words. ${ }^{149}$

Although the PPME did not gain legal recognition yet from the Dutch government, the priciples of its founders can be clearly seen. It was claimed that unity, in particular among the board, had been a priority. ${ }^{150}$ The following relevant activities might be evidence for their strongly held principles. Since its establishment, the board had carried out many beneficial activities such as designing and composing the statutes and bylaws of PPME on April 12, 1971, ${ }^{151}$ producing a bulletin called al-faläh in March 1972, commemoration of the Prophet's birth in April 1972, creating formal and non-formal networks with an Islamic center in Geneva and the Indonesian Ambassador for Switzerland, and Indonesian students in Munich, Germany in the beginning of May 1972, and performing Ramadan activities in the same year. Collecting zakat together with Indonesian embassy and performing idu'l-fitri and 'idu'l-adhà in the Hague were also part of its activities. ${ }^{152}$ Since early 1973, PPME had been working towards legal recognition from the Dutch government. By the middle of 1973, the revision of its statutes and bylaws was done. ${ }^{153}$ In the same year, Badan Usaha Dana (BUD, the Board for Enterprise and Fund Raising) was formed. In June 1973, PPME's representative visited Libya to attend the conference held by the World Assembly of Muslim Youth (WAMY). Still in 1973, meetings with Persatuan Pelajar Indoensia (PPI, the Indonesian Students Association) of Cairo and Medina were held. Then, contacts with Mu'tamar Ālam Islāmī (Pakistan), Rābitat al-

148 Read: Laporan Kerja, 1973.

149 See: Muhamad Hisyam, Persatuan, p. 31-32.

${ }^{150}$ Interview with A. Hambali M., 30 June 2008.

${ }^{151}$ DPP PPME, The Statute, 1973, p. 2.

${ }^{152}$ DPP PPME, Laporan, 1973.

153 The absence of the time limit of PPME existence for 29 years was the main revision of its statute. Read: The State Secretary of Justice, Bijvogsel van de Nederlandse Staatscourant, dated 14 August 1974. 
Ālam Istāmī (Saudi Arabia), and Muslim Student Association (America and Canada) were initiated. A representative of PPME also attended a conference in London held by an Islamic Center. ${ }^{154}$ The facts pertaining to PPME's activities show that during these three years, 1971-1973, there were important actions carried out by this new organization. Initially, although the new organization was structurally independent from the Indonesian Embassy in the Netherlands, they maintained a relationship through joint activities with the embassy. PPME also began creating international connections. ${ }^{155}$ Networking with the foreign organizations mentioned above, without the aid and interference of the Indonesian government, is the proof. Networking was also carried out with Indonesian friends in various countries throughout Europe, America, and Asia. No less important was the request for legal recognition. This recognition hinted at the significant efforts of the boards and supporters of the new organization, despite lack of knowledge of their new milieu as guests in the Netherlands.

\section{After May 1974}

In 1974, PPME was legally recognized by the government on the basis of the Dutch Queen's Letter no. 38 of May 6, 1974 with the status of "vereniging" [association]. ${ }^{156}$ As a matter of fact, most Muslim organizations in the Netherlands had the status of stichting not vereniging. Therefore, the status of the new organization completely differed from them. ${ }^{157}$ Nevertheless, this new Muslim organization benefited from this status. Because of it, PPME required the presence of both its boards and members. ${ }^{158}$ Branches that emerged in cities in the Netherlands and

${ }^{154}$ DPP PPME, Laporan, 1973.

${ }^{155}$ William D. Angel elaborated that the transnational interaction took place when at least one of the actors of the interaction was neither a government nor an intergovernmental organization, and individuals or organizations in a given society could, therefore, interact with foreign governments and foreign societies. They bypassed their own government. William D. Angel, Youth, p. 3-5.

${ }^{156}$ In Hisyam's book (1996, p. 32) the letter numbered 58 of may 4, 1974. However, according to the Bijvoegsel of 1974 and the Queen Letter on the legalization of PPME, it is clearly stated that it was legalized on the date the writer mentioned above.

157 See: Muhamad Hisyam, Persatuan, p. 32.

${ }^{158}$ Interview with William Satriaputra de Weerd, 25 May 2008, Rotterdam. 
Germany were the result of its status of vereniging, enabling its boards to expand and increase its membership. Besides, the branches could operate on the basis of their own characteristics and uniqueness as far as they comported with the guidelines of PPME's mission. ${ }^{159}$

Another advantage was that it reserved the right to create a stichting (foundation). This right was, on the contrary, not given by the stichting. This right was in line with the presence of its members. ${ }^{160}$ This new association had created a stichting, called al-Ittibad, to handle its membership whose number had gone on increasing. ${ }^{161}$ This creation was possible due to the fact that in a vereneging, its member could actively play certain roles. ${ }^{162}$

Despite its flexibility, the status of a vereniging had, unlike a stichting, placed PPME in a problematic position. Important policy, strategies and programs of the organization had to be based upon the decision of a General Meeting, Regional Meeting, Branch Meeting or Extraordinary Meeting. This required the association to take certain and, sometimes, long procedures when making fundamental policies or strategic steps. ${ }^{163}$ This completely differed from the nature of the foundation, which required no membership.

Another problem was the absence of clarification on specific sectors to which the association was directed. Therefore, it was hard for it to receive Dutch subsidies, ${ }^{164}$ in particular for socio-cultural activities rather than religious domains. As a matter of fact, subsidies were frequently given to non-governmental organizations or foundations on the basis of specific socio and cultural needs.

Besides, subsidies or other financial assistance, according to the statutes of PPME, should not bind the association to its donors. ${ }^{165}$ Therefore, assistance was evaluated as to whether it would harm the nature of the association or not. The voices of its branches should be,

${ }^{159}$ Read: Muhamad Hisyam, Persatuan, p. 32-33

${ }^{160}$ Interview with William Satriaputra de Weerd, 25 May 2008, Rotterdam.

161 Read: Muhamad Hisyam, Persatuan, p.. 32-33

${ }^{162}$ Interview with William Satriaputra de Weerd, 25 May 2008, Rotterdam.

${ }^{163}$ Read: “Chapter V-VII”, in DPP PPME, Bylaws of PPME, 1979.

${ }^{164}$ Read: Muhamad Hisyam, Persatuan, p. 33

${ }^{165}$ Read: "Article VII on Finance", in DPP PPME, the Statute of PPME, 1979. 
also, taken into consideration in order to be in line with the statutes of PPME.

The new status of vereniging for PPME seemed to be the best choice. Its statutes and bylaws, and the nature of its membership were the reasons for it. Nonetheless, the impact of this status can be seen from subsequent activities. After the new status, this new association started thinking of possessing a mosque. ${ }^{166} \mathrm{In}$ addition to al-ídain, maulid al-nabiyyi, since the mid-1974-1975, the Islamic commemoration such as isrä' mi'räj, nuzūl al-qur'ann could have been held. At the end of 1974 and 1975, PPME organized a program for the hajj pilgrimage for some of its members. Still, at the end of 1974, Islamic lessons for children were started. These activities were supported by the Indonesian embassy in the Netherlands. Beginning in 1975, Islamic lessons were provided for its adult congregation. ${ }^{167}$ In December 1975, it held leadership training. ${ }^{168}$ On February 25, 1976, the PPME of Germany ${ }^{169}$ visited the Indonesian embassy in Germany in order to introduce themselves and their plans. In March 1976, it conducted a survey, collecting data on Indonesian students in universities in Frankfurt, Giessen, Offenbach and Darmstadt. Still in the same month, on 9 March 1976, a meeting with the representatives of Indonesian student organizations was held. The representatives of Perhimpunan' Pelajar Indonesia (PPI), Keluarga Mahasiswa Katholik Indonesia (KMKI), Persekutuan Kristen Indonesia (Perki) attended the meeting to discuss the possibility of joint activities. On April 17, 1976, leadership training for Indonesian Muslim youths in Frankfurt was held. In August 1976, the revision of PPME's statutes and bylaws was conducted. The main points of revision were to some of the goals and the addition of its honorable member. ${ }^{170}$ In May 1979, the statutes and bylaws of PPME were, again, revised. In this revision, new controlling and autonomous bodies were formed. In addition, special bodies and

${ }^{166}$ DPP PPME, Laporan Kerja 1973-1976 (The Hague: PPME, 1976), p. 10.

167 Ibid., p. 8

${ }^{168}$ Ibid., p. 4-5.

${ }^{169}$ DPW PPME Germany, Laporan Kerja DPW Germany (Giessen: PPME, 1976).

${ }^{170}$ DPP PPME, The Statute and Bylaws of PPME (The Hague: PPME, August 1976), p. 2. 
committees for certain urgent cases were also put forward. ${ }^{171}$ Then, in the beginning of 1985, the regional executive committee of PPME the Netherlands published a bulletin al-Ittihäd. ${ }^{172}$ In September 1992 Dewan Pimpinan Pusat (DPP, the General Executive Committee) was re-formed after its absence since $1982 .{ }^{173}$ In the same month, the revision of its constitution was, for the third time, conducted. At the beginning of 1993, a bulletin called 'Euro Moslem' was published by PPME of Amsterdam Branch. ${ }^{174}$

As can be seen, over a period of almost eighteen years, from April 1974 - January 1993, this association increased its activities. On the other hand, international interactions decreased, beginning in the early 1980s. During this period, this organization apparently recommended the performing of commemorations of historic Islamic events as mentioned above. This accommodation hinted at the openness of its members who, in fact, came from heterogeneous socio-religious backgrounds. Then, the relationship with the Indonesian government became more intimate. Its relationship with the Indonesian Embassy in Germany, in addition to that in the Netherlands, is evidence. The openness of this organization was also proven. It even passed over the religion of Islam. This can be seen from its meeting with the Catholic and Protestant organizations of Indonesian students as mentioned above. Lastly, this period also produced many flyers that played a significant role in the publication, networking, as the media of information exchange, and expression of members' aspirations of PPME.

\section{After August 1993}

According to the letter of the Dutch Chamber of Commerce and Industry, dated December 14, 1994, on vereniging and stichting, PPME had been, since 1 September 1993, registered as a vereniging with a limitless amount of time to operate. This new status was extremely significant for its boards and members. The Dutch government, at least through

${ }^{171}$ DPP PPME, The Statute and Bylaws of PPME (Giessen: PPME, 1979).

172 PPME, Al-Ittihaad, No. 19 (The Hague: PPME, Maart-April 1988).

${ }^{173}$ DPW the Netherlands, Laporan Pertanggungjawaban Program Kerja (The Hague: PPME, 1994), p. 6-7.

${ }^{174}$ DPC PPME Amsterdam, Euro Moslem, No. 8 (Amsterdam: PPME, 1994). 
this letter, continued to recognize PPME as an active and responsible Muslim organization. The letter also suggested that its existence in the Netherlands was needed by its people, who were mostly Indonesian. The following activities would show whether they could benefit from this new status or go in the opposite direction.

In October 1994 the association was recognized as an active member of WAMY (World Assembly of Muslim Youth). This did not take place by accident but as the result of its involvement as a member of the world assembly since 1977. ${ }^{175}$ Then, Al-Mu'minun, the Islamic teaching for a group of Dutch speakers, was founded on 2 July 1995. ${ }^{176}$ From September 1995 to April 1996, PPME was involved in the process of obtaining possession of a mosque, called later al-Hikmah in The Hague. This mosque had been, since July, under the management of the Indonesian Embassy in The Netherlands. ${ }^{177}$ In 1995 Zikra, another bulletin owned by PPME, was published. ${ }^{178}$ For the second generation, ${ }^{179}$ the Jeugdkamp (youth camp) program was held in 1995 and 1996. Islamic education and organization subjects were intensively taught in the program. Besides, in 1996 and 1997, a contest of reciting al-Qur'an for the successors of the first generation was also held. The

${ }^{175}$ DPW PPME the Netherlands, Laporan Pertanggungjawaban Program Kerja PPME Wilayah Nederland 1992-1994 (The Hague: PPME, 27 November 1994), p. 22.

${ }^{176}$ DPC PPME Den Haag, Laporan Pertanggungjawaban Program Kerja 2000-2002 (The Hague: PPME, September 2002), p. 5.

177 Read: The Caretaker of Masjid al-Hikmah, Memorandum Akbir Jabatan, KBRI: The Hague, 1997, p. 3-5. It is worth mentioning that the success of KBRI in owning the building functioned as the place for worship and social activities could not be disassociated from the efforts of PPME's figures. Interview by phone with the former leader of PPME the Netherlands, Naf'an Sulchan, 10 May 2008, at 20.00. His opinion was in line with that of the chairperson of Regional PPME the Hague 1994-1996 stating that in the program of commemorating of The Prophet's birth in 1995 PPME initiated the effort to found a mosque. Read: DPW PPME the Netherlands, Laporan Pertanggungjawaban DPW Nederland 1994-1996 (PPME: The Hague, 1997), p. 9.

${ }^{178}$ DPC PPME, Zikera, The Hague: PPME, 1997.

179 The experience that had been undergone by Persatuan Umat Islam, the predecessor of PPME, was not in the hope of PPME boards and members. It structurally existed but was meaningless. It was merely a document. DPW PPME the Netherlands, Laporan Pertanggungjawaban Program Kerja PPME Wilayah Nederland 1997-1999 (The Hague: PPME, 2000), p. 8. 
bulletin al-Ittihad served as the vehicle for the publications of PPME. ${ }^{180}$ At the end of 1996, PPME set out to perform the program of 'umrah, particularly, for the second generation. However, this program was delayed due to the participants not yet reaching the minimum number required. ${ }^{181}$ On January 26, 1997, one of PPME's central figures was involved in the program of pesantren kilat (short Islamic school) aimed at improving the Islamic knowledge and understanding of Indonesian Muslims in the Netherlands. This program was held in the al-Hikmah mosque. ${ }^{182}$ On August 10, 1997, PPME of Amsterdam conducted a sport day for its members which aimed at the strengthening of social relations. ${ }^{183}$ Additionally, between 1997-1999, other activities occurred. There was an initiative to publish other bulletins as the vehicle for academic and da'wa, paying more attention to other branches. "Euro Muslim" for the Amsterdam branch and "Iqra"” for Rotterdam branch were prioritized. ${ }^{184}$ This association was also concerned with improving the performance of the pilgrimage. ${ }^{185}$ Between the years 2000-2002, Islamizing a nonMuslim was permitted to be handled by PPME. Over these two years, there were 135 registered converts. It conducted and witnessed mixed nationality marriages under Indonesian Islamic law, in particular, the marriage of an Indonesian to a Dutch person. These marriages were nine in total. ${ }^{186}$ On October 2004, in Ramadan activities, the method of dawrah was introduced to the teachers of PPME Amsterdam. The Quranic recitation competition was held for the Islamic students of the

${ }^{180}$ Read: DPW PPME the Netherlands, Laporan Pertanggungjawaban, 1997, p. 8

${ }^{181}$ Ibid., p.12.

182 The Caretaker of Masjid al-Hikmah, Pesantran Kilat Ramadhan 1417 H (The Hague: Pilar, 1997), p. 5-14.

${ }^{183}$ PPME Amsterdam, Laporan Kegiatan Musim Panas Barbeque dan Budaya Periode 1996-1997 (Amsterdam: PPME, 1997).

${ }^{184}$ DPW PPME the Netherlands, Laporan Pertanggunganjawab DPW PPME Wilayah 1997-1999 (PPME: The Hague, 2000), p. 7.

185 Ibid., p. 9.

186 DPC PPME Den Haag, "Lampiran 4”, in DPC PPME, Laporan Pertanggungjawaban, 2002, p. 1-3. 
PPME Amsterdam. ${ }^{187}$ Beginning in November 2005, monthly Islamic lectures, both in Indonesian and Dutch, were held. ${ }^{188}$ Still in this year, the PPME Amsterdam purchased a large building for religious activites. Lastly, during 2006-2009, PPME attempted to establish contacts with Indonesian and Dutch organizations for transnational activities. ${ }^{189}$

From these facts, it can be asserted that this association paid special attention to the presence of Dutch speaking Muslims. They were mostly Dutch, and were well organized in a group called "al-Mu'minun". Furthermore, it was very concerned with the religious knowledge of PPME's second generation. The intensive programs provided for them are proof of its concern. This period is also notable for the purchase of a place for worship and socio-cultural activities. No less importance was that this association had been able to frequently perform Islamic marriage and legalize a person who wished to be Muslim according to the shar' $a$. Last but not least, it seemed that in this last period, its boards did not maximize its status as an association with no time limits on its operations. This can be seen in the lack of international co-operations, particularly, with non-Islamic adherents. Nevertheless, the biggest achievement of this last period was the purchase of a house made to function as a mosque in 2005.

${ }^{187}$ PPME Amsterdam, Jadwal Kegiatan pada Minggu Ketiga dan Minggu Ke-empat Ramadhan Th. 2004 (Amsterdam: PPME, 2004).

188 PPME Majlis Dzikir, Mededeling (Amsterdam: PPME, 2005).

189 DPC PME Al-Ikhlash, Tugas, Tanggungjawab, dan Program Kerja (Amsterdam: PPME al-Ikhlas, February 2006). 


\section{BIBLIOGRAPHY}

Angel, William D., Youth Movement of the World, UK: Longman, 1990

Arps, B. et. al, (eds.), Bijdragen, No. 154.2, Leiden: KITLV, 1998.

Barton, Greg, Gus Dur: the Authorized Biography of Abdurrahman Wabid, Jakarta-Singapore: Equinox, 2002.

van Dijk, C., Rebellion under the Banner of Islam: the Darul Islam in Indonesia, The Hague: Martinus Nijhoff, 1981.

van Dijk, C. and de Groot A. H., (eds.), State and Islam, Leiden: CNWS, 1995.

DPC PPME Amsterdam, Euro Moslem, No. 8, Amsterdam: PPME, 1994.

DPC PPME, Laporan Pertanggungjawaban PPME Cabang Den Haag 19961997, The Hague: PPME, December 1997

DPC PPME Den Haag, Laporan Pertanggungjawaban Program Kerja 20002002, The Hague: PPME, September 2002.

DPC PPME, Proposal for the Construction of a Mosque for the Indonesian Community in the Netherlands (Rotterdam), Rotterdam: PPME, January 2004.

DPC PPME al-Ikhlash, PPME al-Ikblash Amsterdam Ledenlijst, Amsterdam: PPME, n.d.

DPC PPME, Zikra, The Hague: PPME, 1997.

DPC PPME, Laporan Pertanggungjawaban Program Kerja PPME The Hague Branch 2000-2002, PPME: The Hague, September 2002.

DPC PME Al-Ikhlash, Tugas, Tanggungjawab, dan Program Kerja, Amsterdam: PPME al-Ikhlas, February 2006.

DPP PPME, Laporan Kerja 1973-1976, The Hague: PPME, 1976.

----, The Statute and Bylaws of PPME, The Hague: PPME, August 1976.

----, The Statute and Bylaws of PPME, PPME: Giessen, 1979.

----, Daftar Peserta Musyawarah Umum IV, The Hague: PPME, 1982.

----, The Bylaws of PPME, The Hague: PPME, 1979.

----, Laporan DPP Musyawarah I, The Hague: PPME, 1973.

DPW PPME Germany, Ikrar Musyawarah Wilayah Luar Biasa 1982, 
Germany: PPME, November 1982.

----, Laporan Kerja DPW PPME, Darmstadt: PPME, July 1976.

----, Laporan Kerja DPW Germany, Giessen: PPME, 1976.

DPW PPME the Netherlands, Laporan Umum Pengurus PPME Wil. Nederland 1984-1986, The Hague: PPME, 1986.

----, Laporan Pertanggungjawaban Program Kerja PPME Nederland 1992-1994, The Hague: PPME, 1994.

----, Laporan Pertanggungjawaban Program Kerja, The Hague: PPME, 1994.

----, Laporan Pertanggungjawaban Program Kerja PPME Wilayah Nederland 1992-1994, The Hague: PPME, 1994.

----, Laporan Pertanggungjawaban Program Kerja PPME Periode 1992-1994, The Hague: PPME, November 1994.

----, Laporan Pertanggungjawaban DPW Nederland 1994-1996, PPME: The Hague, 1997.

----, Laporan Pertanggungjawaban Program Kerja PPME Wilayah Nederland 1997-1999, PPME: The Hague, 2000.

----, Laporan Pertanggunganjawab DPW PPME Wilayah 1997-1999, PPME: The Hague, 2000, p. 7.

----, Keputusan PPME Wilayah Nederland, No. 2/PPMENL/XII/2005, The Hague: DPW PPMW, 18 December 2005.

----, Laporan Pertanggungjawaban Program Kerja PPME Wilayah Nederland Periode 1997-1999, The Hague: PPME, Juni 2000.

----, Surat untuk. M. Zubaidi, No. OX/KWN/01/93 dated 08-01-1993, The Netherlands: PPME, 1993.

Fatimah, Siti, Laporan Notulen Rapat ke-Empat Pengurus Majlis Drikir, Amsterdam: PPME Majlis Dzikir, 31 December 2005

Gunawan, Basuki, Indonesische Studenten in Nederland, The Hague: N.V. Uitgeverij W. van Hoeve, 1966.

Hisyam, Muhamad, Persatuan Pemuda Muslim Se Eropa, The Hague: YMAE, 1996.

http:// achmad-supardi.blogspot.com/2005_10_01 archive.html, quoted at 11:59 of 21 July 2008.

bttp:/ / counterterrorisminfo.wordpress.com/2002/12/24/ abdul-wabid-kadungga, 
Sujadi

quoted on 23 July 2008 at 01:27 a.m.

http:/ / wwm.munindo.brd.de/artikel/ artikel_04/000129_3.btm, quoted on 23

July 2008 at 01:11 a.m.

http:/ / mmm.ppme.nl/Nederland/Geschied.btm, quoted on 20 July 2008.

Husin, Asna, Pbilosophical and Sociological Aspects of Da'wab: a Study of Dewan

Dakwah Islamiyah Indonesia, USA: UMI, 1998.

Kettani, M. Ali, Muslim Minority in the World Today, London and New York:

Manshell Publishing Limited, 1986.

Konperensi Pelajar Indonesia se-Eropa, Hennef: Panitia Konperensi, 1955.

Maryadie, M, F, A, Sumbangan Pemikiran kepada Musyawarah Umum PPME II, London, 21 July 1976.

Maura I. Toro and Marixsa Alice, Migration and Immigration: a Global View, USA: Greenwood Press, 2004.

Nonneman, Gerd, et. al., Muslim Communities in the New Europe, UK: Garnet Publishing, 1996.

PPME, Al-Ittihaad, No. 19, The Hague: PPME, 1988.

PPME Amsterdam, Laporan Kegiatan Musim Panas Barbeque dan Budaya Periode 1996-1997, Amsterdam: PPME, 1997.

----, Jadwal Kegiatan pada Minggu Ketiga dan Minggu Ke-empat Ramadhan Th. 2004, Amsterdam: PPME, 2004.

PPME Majlis Dzikir, Mededeling, Amsterdam: PPME, 2005.

Purwoko, Dwi, Pemuda Islam di Pentas Nasional, Jakarta: Bonafida Cipta Pratma, 1993.

Rashid, Sadia Rashid (ed.), Hamdrad Islamicus, April-June, Vol. XXX, No. 2, Pakistan: Hamdrad Foundation, 2007.

Sabili, No. 16, Year XII, 27 February 2004.

Shadid, W.A.R., and van Koningsveld, P.S., Muslims in the Margin, Kampen: Kok Pharos, 1996.

----, Religious Freedom and the Position of Islam in Western Europe, Kampen: Kok Pharos, 1995.

----, (eds.), The Integration of Islam and Hinduism in Western Europe, Kampen: Kok Pharos, 1991. 
Stokhof, W.A.L., and Kaptein, N.J.G. (eds.), Beberapa Kajian Indonesia dan Islam, Jakarta: INIS, 1990.

The State Secretary of Justice, Bijvogsel van de Nederlandse Staatscourant, dated 14 August 1974.

The Caretaker of Masjid al-Hikmah, Memorandum Akhir Jabatan, KBRI: The Hague, 1997.

Zaibar, Abdul Manan, The Indonesian Program for the Islamic Religious Education of the Indonesian Children in the Netherlands (Thesis), Leiden: INIS, 2003. 
Sujadi 